УДК 371.3(378)

Богунов Сергій, кандидат технічних наук, Національний університет оборони України імені Івана Черняховського, м. Київ, ORCID ID 0000-0002-4946-1604

Вітер Дмитро, доктор філософських наук, старший науковий співробітник, Національний університет оборони України імені Івана Черняховського, м. Київ,

ORCID ID 0000-0002-7330-1280

Мітягін Олег, кандидат історичних наук, Національний університет оборони України імені Івана Черняховського, м. Київ, ORCID ID 0000-0003-1941-3561

Кітура Олег

Національний університет оборони України імені Івана Черняховського, м. Київ,

ORCID ID 0000-0003-0434-8277

DOI: $10.33099 / 2617-1775 / 2019-02 / 07-15$

\title{
СИСТЕМА ВІЙСЬКОВОЇ ОСВІТИ І ПІДГОТОВКИ У КРАЇНАХ- ЧЛЕНАХ НАТО (БОЛГАРІЯ, УГОРЩИНА, ЧЕХІЯ, СЛОВАЧЧИНА)
}

Досліджено систему підготовки військових фахівиів, офіцерських кадрів різних ступенів та ланок військового управління у країнах-членах НАТО (колишніх членів організації Варшавського договору). Наведено загальну структуру підготовки офіцерських кадрів збройних сил Болгарії, Угорщини, Чехії та Словаччини. Показано принциии відбору, зміст навчального прочесу, підвищення кваліфікащії офічерських кадрів у системі військової освіти цих країн. Доведено необхідність та можливість використання досвіду країн-членів НАТО у сфері підготовки офіцерських кадрів задля потреб реформування системи військової освіти України з метою імплементаиії відповідних стандартів НАТО.

Ключові слова: військова освіта; підготовка військових фахівців; НАТО; офічерські кадри; система; навчальний прочес.

Постановка проблеми. Існуючи та потенційні загрози національній безпеці й територіальній цілісності України вимагають перегляду сталої системи військової освіти. Перед офіцерськими кадрами та військовими спеціалістами сьогодні постають нові завдання, складність яких обумовлює потребу якісного оновлення змісту їх підготовки. Наразі триває процес переходу військової освіти України від радянської моделі до стандартів НАТО в системі підготовки військових фахівців, метою чого має стати підвищення рівня боєготовності та боєздатності збройних сил, забезпечення й зміцнення обороноздатності держави. Схожим шляхом, у процесі євроатлантичної інтеграції, йшли країни, що були членами організації Варшавського договору (зокрема, Болгарії, Угорщини, Чехії, Словаччини), й наразі є членами НАТО, для яких вища військова освіта $є$ одним із пріоритетних факторів розвитку 
систем національної безпеки та оборони. Досвід вдосконалення системи військової освіти, набутий цими країнами має бути урахований Україною на шляху реформування національних збройних сил, що передбачає не тільки кількісні зміни, але й якісні, які стосуються, перш за все, рівня підготовки військових фахівців.

Метою статі є аналіз досвіду та визначення основних засад і принципів системи військової освіти та підготовки військових фахівців у країнах-членах НАТО (Болгарія, Угорщина, Чехія, Словаччина).

Методи дослідження. У статті використано систему загальнонаукових i спеціальних методів теоретичного та емпіричного дослідження (аналіз наукової літератури з досліджуваної проблеми, систематизація та узагальнення, логічнопорівняльний методи, системний підхід, контент-аналіз).

Виклад основного матеріалу. Підготовка осіб на посади офіцерського складу тактичного рівня для сухопутних військ та військ повітряної оборони 3С Республіці Болгарія (далі - РБ) здійснюється у Національному військовому університет імені Василя Левського (далі - НВУ) [3]. Зазначена підготовка здійснюється за очною формою навчання за ступенем вищої освіти “бакалавр” й проводиться в галузі знань "Військова справа“" за спеціальністю “Організація та управління військовими підрозділами на тактичному рівні“" 3 відповідними спеціалізаціями. Курсанти, які виконали навчальний план та успішно склали державний іспит (захистили дипломну роботу), отримують два дипломи: ступеня бакалавр за відповідними спеціальностями (військова кваліфікація) “офіцер тактичного рівня управління"; за професійною кваліфікацією, що відповідає цивільній спеціальності. Термін навчання за всіма військовими спеціалізаціями і відповідними цивільними спеціальностями становить 5 років.

Підготовка осіб офіцерського складу на посади оперативного рівня здійснюється у Військовій академії "С. Раковський“ (далі - ВА) 3 числа офіцерів, які мають тактичний рівень підготовки [1; 2]. Випускники ВА отримують вищу освіту ступеня "магістр" за спеціальністю “Організація і управління військовими формуваннями на оперативному рівні“" в галузі "Військова справа". Навчання здійснюється за спеціалізаціями: "Сухопутні війська"; "Військово-повітряні сили"; "Військово-морські сили"; “Логістика"; "Комунікаційні та інформаційні системи"; “Адміністративні процеси та заходи"; "Інформація про безпеку та оборону”. Термін навчання за очною формою становить 1 рік. Ступінь вищої освіти “магістр” можуть отримати офіцери, які мають ступень “бакалавр” у професійній військової галузі, здобутий у вищих військових навчальних закладах РБ або за кордоном.

Підготовка осіб офіцерського складу на посади стратегічного рівня здійснюється у Військової академії “С. Раковський” з числа тих офіцерів, які мають оперативний рівень підготовки. Випускники ВА отримують вищу освіту ступеня "магістр" за спеціальністю "Стратегічне управління обороною i збройними силами" в галузі "Військова справа" та кваліфікацію "Офіцер стратегічного рівняю управління обороною і збройними силами”. Термін навчання за очною формою становить 1 рік. 
Вся військова підготовка в Угорщині зосереджена на факультеті військових наук та підготовки офіцерів Національного університету державної служби Угорщини (далі - НУДС), в якому передбачені наступні основні форми навчання [6;7]:

- 5-річна університетська освіта для цивільних осіб в галузі безпеки та політики оборони, управління обороною, а також зв'язок та управління інформаційними системами;

- 4-річна підготовка офіцерських кадрів тактичного рівня;

- 2-річна очна та 3-річна заочна післядипломна підготовка;

- різні короткострокові післядипломні спеціалізовані курси (наприклад, однорічний курс військового коледжу, однорічний курс інтенсивної мовної підготовки, професійне підвищення кваліфікації тощо).

На бакалаврських курсах факультету навчаються тільки офіцери-кадети (курсанти). Їхній статус регулюється відповідними актами. Офіцер-кадет (курсант) в армії - це студент, який обирає професійну військову кар'єру, після вступу в НУДС підписує освітній контракт зі Збройними Силами Угорщини та має військове звання офіцера-кадета (курсанта). Основною вимогою при прийомі на бакалаврські програми факультету є визнаний державою сертифікат мовного рівня В2 або еквівалентний документ екзамену з англійської мови. Після завершення програми бакалаврського рівня студенти можуть продовжити навчання в магістратурі або розпочати військову кар'єру у Збройних Силах Угорщини.

Програми бакалаврського рівня розробляються за напрямами [6]:

- військове керівництво;

- військове технічне обслуговування;

- військова авіація;

- військова логістика.

До навчання в магістратурі приймаються тільки офіцери з військовим званням капітана або майора. Кандидат повинен отримати попередній дозвіл на прийом від начальника Генерального штабу ЗС Угорщини, а також пройти базову експертизу з державної служби.

Програми магістерського рівня розробляються за напрямами [6]:

- військове керівництво;

- військове технічне обслуговування;

- логістика військових операцій.

Термін навчання на стратегічному та оперативному рівнях підготовки складає 11 місяців.

Підготовку військових фахівців 3 вищою освітою для Збройних Сил республіки Чехія (далі - 3С РЧ) зосереджено в єдиному вищому військовому навчальному закладі - Університеті оборони (далі - Університет), який, як і всі військово-навчальні заклади, інтегрований в загальну систему освіти РЧ [5].

В Університет приймаються випускники середнього військово-технічного училища, які проходять військову службу в званні прапорщика та інші особи, які отримали повну середню освіту. Університет готує фахівців військової 
справи, які можуть служити офіцерами як у ЗС РЧ, так і в інших силових відомствах. Також заклад проводить наукові дослідження в інтересах Міністерства оборони. За військову освіту в Університеті відповідає заступник міністра оборони з кадрових питань.

Університет здійснює підготовку за двома основними напрямами: перший - університетська освіта, що акредитована за трьома рівнями вищої освіти; другий - неакредитовані післядипломні курси для офіцерів, як постійна (упродовж кар'єри) освіта військовослужбовців.

Навчання в Університеті організовано за ступеневою схемою 3 відповідними освітніми рівнями [5]:

- ступінь “бакалавр" з терміном навчання 3-4 роки, по завершенню якого випускник може обіймати посади командира взводу, роти або їм рівні. Наступні 2 роки - підготовка на факультетах військових технологій і захисту від засобів масового ураження, що дає можливість отримати кваліфікацію “інженер”. По завершенню навчання випускник може обіймати посади рівня командира батальйону;

- ступінь “магістр” з терміном навчання 5-6 років, по завершенню якого випускник може обіймати посади старших офіцерів;

- ступінь "доктор філософіï" з термін навчання в докторантурі 3 роки, по завершенню якого випускник може обіймати генеральські посади.

Жорсткі вимоги щодо акредитації університетських освітніх програм забезпечують високопрофесійний рівень викладачів. Освіта, здобута в Університеті, цілковито відповідає освіті в цивільних закладах і дає можливість офіцерам отримати спеціальність, що сприяє кар'єрному росту в цивільному секторі. На цей час в Університеті акредитовано сім навчальних програм i дванадцять навчальних модулів (спеціалізацій), що передбачає підготовку бакалаврів, магістрів та докторів філософії в наступних галузях знань: загальновійськова; військове управління; економіка; інженерія; медичне обслуговування. Наприклад, за програмою військового управління здійснюється підготовка командирів сухопутних підрозділів, зокрема командирів механізованих/танкових підрозділів, загальновійськових командирів, командирів розвідувальних підрозділів, командирів інженерних, артилерійських підрозділів.

Виконання завдань щодо проведення освітніх та науково-дослідницьких заходів в галузі безпеки, військової стратегії, стратегічного управління та лідерства в Університеті покладено на Центр безпеки та військово-стратегічних досліджень. Центр проводить навчання за такими напрямами: підготовка слухачів за акредитованими навчальними програмами; курс для старших офіцерів; курс для офіцерів генерального штабу; курс для фахівців стратегічного управління обороною.

Курс для старших офіцерів - це кар'єрний курс, призначений для офіцерів у званні капітан, які мають передумови для кар'єрного росту. Курс $є$ загальним для всіх спеціальностей а його метою є підготовка офіцерів до:

- командування батальйоном, дивізіоном, ескадрилью; 
- виконання управлінських функцій на рівні керівника відділу штабу бригади, полку, крила, компоненту сили, агенції, генерального штабу;

- моніторинг функціонування військових підрозділів оперативного рівня, у тому числі до рівня узгодження дій з генеральним штабом;

- призначення на відповідні посади в національних представництвах та персоналу НАТО/ЄС/ОБСЕ/ООН.

До навчання на курсі можуть бути допущені офіцери - випускники ад'юнктури чи магістратури зі ступенем володіння англійською мовою на рівні щонайменше 3,2,3,2 (за стандартами STANAG 6001).

Курс для офіцерів генерального штабу призначений для старших офіцерів у військовому званні не нижче підполковника, які мають передумови для призначення на командні та керівні посади, що передбачають наявність у кандидата військової освіти стратегічного рівня. Метою курсу є підготовка офіцерів до виконання функціональних обов'язків, серед яких: командування на рівні бригади, полку крила; офіцера на рівнях агентства, генерального штабу; командування в національних представництвах у НАТО/СС/ОБСЄ/ООН. На курсах офіцер отримає навички стратегічного військового управління щодо забезпечення безпеки і захисту держави, а також здатності концептуально розробляти, впроваджувати та керувати процесом побудови та розвитку оборонної сфери країни. До навчання на курсі можуть бути допущені офіцери - випускники ад'юнктури чи магістратури зі ступенем володіння англійською мовою на рівні щонайменше 3,3,3,3 (за стандартами STANAG 6001).

Курс для фахівців стратегічного управління обороною призначений для державних службовців міністерства оборони або інших державних органів, пов'язаних 3 виконанням обов'язків у сфері державного захисту на рівні стратегічного управління. Метою програми навчання $\epsilon$ нарощування знань та вмінь фахівців у стратегічному управлінні обороною, формування компетентностей для проведення стратегічного аналізу зовнішнього середовища та оцінки внутрішніх характеристик державної оборонної системи, формулювання сучасного напряму державної оборонної системи та розроблення стратегічних документів для захисту держави.

Підготовка військових фахівців 3 вищою освітою для збройних сил Словацької республіки (далі - СР) зосереджена в єдиному державному вищому військовому навчальному закладі - Академії збройних сил (далі - Академія), яка $\epsilon$ окремим підрозділом у структурі збройних сил країни. Ректор Академії призначається президентом Словацької республіки, підпорядковується міністру оборони та є підзвітним сенату академії [4]. Академія інтегрована у загальну систему вищої освіти країни на засадах єдиної нормативно-правової бази.

У СР передбачено три шляхи отримання вищої військової освіти та первинного військового звання:

1. Відповідно до контракту, укладеному між академією та цивільними ВНЗ, передбачено 5 річний термін навчання - для спеціалістів військової авіації та військових медиків за схемою “3+2” (3-річний термін - для здобуття ступеня 
бакалавра та 2-річний - для здобуття ступеня магістра. Така модель підготовки покриває більшість потреб словацьких збройних сил у офіцерських кадрах. Варто зауважити, що завершення бакалаврату є проміжним етапом підготовки та не дозволяє отримати військове звання і продовжити службу в якості офіцера збройних сил СР.

2. Ступінь вищої освіти “магістр" 3 терміном навчання у 2 роки здобувається в Академії (Авіаційному факультеті Технічного університету) особами, які отримали ступень вищої освіти “бакалавр” в інших цивільних ВНЗ за спорідненими спеціальностями.

3. Навчання на курсах при видовому ВВНЗ провадиться особами, які мають ступень вищої освіти магістр за спорідненою цивільною спеціальністю. Такий курс може тривати до 1 року в залежності від спеціальності. Зазначена форма, в основному, застосовується для підготовки офіцерських кадрів рідкісних військових спеціальностей.

У Академії збройних сил навчаються особи, які здобувають первинне офіцерське звання та офіцери словацьких збройних сил (країн-партнерів), які здійснюють своє професійне вдосконалення на різноманітних курсах підготовки. Академія збройних сил здійснює підготовку військових фахівців в рамках акредитованих навчальних програм за трьома рівнями освіти.

Перший рівень освіти терміном три роки закінчується присвоєнням випускнику ступеня вищої освіти “бакалавр” за наступними спеціальностями [4]:

"Безпека та оборона держави";

"Електронні системи озброєння";

"Електронні системи";

"Управління військовими організаціями";

“Комп'ютерні системи, мережі та послуги";

“Військовий зв'язок та інформаційні системи”;

“Системи озброєння, зброя та ії частини”.

Другий рівень освіти тривалістю два роки передбачає отримання академічного ступеня “магістр" або "інженер" за спеціальностями [4]:

"Безпека та оборона держави";

"Електронні системи озброєння";

“Військовий зв'язок та інформаційні системи”;

"Системи озброєння, зброя та ії частини".

Третім рівнем освіти є докторантська навчальна програма, яка триває три роки у денній формі освіти та п'ять років у заочній. По закінченню навчання присвоюється академічний ступінь “PhD” (“доктор філософіï”) за наступними спеціальностями:

"Безпека та оборона держави";

"Електронні системи озброєння";

“Військовий зв'язок та інформаційні системи”.

Навчання у системі військової освіти Словацької республіки здійснюється протягом всього періоду військової служби шляхом 
стаціонарного навчання у ВВНЗ, навчання на курсах підвищення кваліфікації, які передують призначенню на нову посаду та отримання чергового військового звання.

Висновки та перспективи подальших наукових розвідок. Підсумовуючи досвід підготовки офіцерського складу країнами Східної Свропи, які були членами Варшавського договору, й на разі є членами НАТО, можна зазначити, що у системах військової освіти цих країн значні зусилля спрямовані на якісний відбір кадрів для сил безпеки і оборони. У розглянутих країнах військові університети (академії, коледжі) які готують військових фахівців оперативного та стратегічного рівнів, а також цивільних фахівців для сектору оборони держави, підпорядковуються безпосередньо міністерствам оборони.

\section{ЛІТЕРАТУРА}

1. Висше военно-морске училище “Н.Й. Вацаров" [Електронний ресурс]. - Режим доступу : https//www.naval-acad.bg.

2. Закон за отбраната и въоръжените сили на республика България [Електронний pecypc]. - Режим доступу : https//www.lex.bg.

3. Националният воене университет «Васил Левски [Електронний ресурс]. - Режим доступу : https//www.nvu.bg.

4. Уліч В. Армія Словаччини: прогрес після вступу в НАТО / В. Уліч, Ю. Черних, О. Черних // Оборонний вісник. - № 5. - 2019. - С. 20-27.

5. Черних Ю. Не числом, а вмінням // Ю. Черних, О. Черних // Оборонний вісник. - № 7. $-2019 .-$ C. $20-27$.

6. National University of Public service. - Hungary, Budapest: National University of Public service, 2017. - [Електронний ресурс]. - Режим доступу : https://en.uni-nke.hu.

7. Szaby M. University level education in Hungarian ational defence. Formation and main experiences / Miklys Szaby // Academic and Applied Research in Military Science (AARMS). Hungary, Budapest: National University of Public service, 2004. - Vol. 3, No. 1 - pp. 3-20.

\section{REFERENCES}

1. Vysche voenno-morske uchilistche "N.J. Vatzarov". - URL : https//www.naval-acad.bg.

2. Nacionalnijat voene universitet "Vasyl Levsky". - URL : https//www.nvu.bg.

3. Zakon za otbranata i vooroszenite syly na respublika Bolgaria. - URL : https//www.lex.bg.

4. Ulich V. Armia Slovachchiny: progress pislia vstupu v NATO / V. Ulich, J. Chernyh, O. Chernyh //Oboronny visnyk. - № 5. - 2019. - C. 20-27.

5. Chernyh J. Ne chislom, a vminnjam / J. Chernyh, O. Chernyh // Oboronny visnyk. - № 7. 2019. - C. 20-27.

6. National University of Public service. - Hungary, Budapest: National University of Public service, 2017. - [Електронний ресурс]. - Режим доступу : https://en.uni-nke.hu.

7. Szaby M. University level education in Hungarian ational defence. Formation and main experiences / Miklys Szaby // Academic and Applied Research in Military Science (AARMS). Hungary, Budapest: National University of Public service, 2004. - Vol. 3, No. 1 - pp. 3-20.

\section{PEЗЮME}

Богунов Сергей, кандидат технических наук, Национальный университет оборони Украины, г. Киев имени Ивана Черняховского

Витер Дмитрий, 
доктор философских наук, старший научный сотрудник, Национальный университет оборони Украины имени Ивана Черняховского, г. Киев

Митягин Олег, кандидат исторических наук, Национальный университет оборони Украины имени Ивана Черняховского, г. Киев

Китура Олег

Национальный университет оборони Украины имени Ивана Черняховского, г. Киев

\section{Система военного образования и подготовки в странах-членах НАТО (Болгария, Венгрия, Чехия, Словакия)}

Исследовано систему подготовки военных специилистов, офицерских кадров различных ступеней и уровней военного управления в странах-членах НАТО (бывиих участнич организачии Варшавского договора). Приведено общую структуру подготовки офицерских кадров вооруженных сил Болгарии, Венгрии, Чехии и Словакии. Показано принципь отбора, содержание учебного процесса, повышения квалификащии офищерских кадров в системе военного образования этих стран. Доказана необходимость и возможность использования опыта стран-членов НАТО в сфере подготовки офищерских кадров в прочессе реформирования системь военного образования Украинь с иелью имплементации соответствующих стандартов НАТО.

Ключевые слова: военное образование; подготовка военных спечиалистов; НАТО; офицерские кадры; система; учебный проиесс.

\section{SUMMARY}

Serhii Bohunov, $\mathrm{PhD}$ (Technical sciences)

National Defense University of Ukraine named after Ivan Cherniakhovskyi, c. Kyiv

Dmitry Viter,

Dr. (Philosophical sciences), senior researcher

National Defense University of Ukraine named after Ivan Cherniakhovskyi, c. Kyiv

Oleh Mitiagin,

$\mathrm{PhD}$ (Historical sciences)

National Defense University of Ukraine named after Ivan Cherniakhovskyi, c. Kyiv

Oleh Kitura

National Defense University of Ukraine named after Ivan Cherniakhovskyi, c. Kyiv

\section{System of the military education and training for NATO state-members (Bulgaria, Hungary, Czech and Slovak)}

Introduction. Today is very important to deepen and develop scientific maintenance of military education in Ukraine, generalization, systematization, comprehension and integration of positive experience of military education formation and development, NATO officers' training within educational process.

Purpose. Analyze the experience of military specialists' education and training within the NATO state-members (Bulgaria, Hungary, Czech and Slovak). 
Methods. The system of general scientific and special methods of theoretical and empirical research (analysis of scientific literature, systematization and generalization of materials, logic and comparative, content analysis) was used in order to realize the article purpose.

Results. The article deals with educational system and training of military specialists in different educational and military command level. A general structure of Bulgaria, Hungary, Czech and Slovak Armed Forces officers training provides. It is show the principles of selection, the educational process content, the training of officers and military specialists in the system of military education in Bulgaria, Hungary, Czech and Slovak.

Originality. Education and training of military specialists in the Bulgaria, Hungary, Czech and Slovak Armed Forces is considered as an integral and level-based system, which is compatible with system of NATO officers' training. Experience of formation and functioning of officers' training in different military educational establishment of this states, and their theoretical and practical training can be practical for military education system of Ukraine.

Conclusion. The transformation of military specialists training system in Bulgaria, Hungary, Czech and Slovak is base on innovative approaches implementation to national security and defense system, of it armed forces development, new requirements for military specialists training, contemporary models of military specialists training, which in the NATO state-members accepted.

Key words: educational process; military education; military specialists; military training; NATO; system. 